\title{
What is the Role of Subcutaneous Single Injections on the Behavior of Adult Male Rats Exposed to Drugs?
}

\author{
R. ŠLAMBEROVÁ ${ }^{1}$, K. NOHEJLOVÁ ${ }^{1}$, A. OCHOZKOVÁ ${ }^{1}$ L. MIHALČÍKOVÁ ${ }^{1}$ \\ ${ }^{1}$ Department of Physiology, Third Faculty of Medicine, Charles University, Prague, Czech Republic
}

Received March 27, 2018

Accepted September 17, 2018

\section{Summary}

Psychostimulants, as well as cannabinoids, have been shown to significantly affect a great variety of behaviors in both humans and laboratory animals. Our previous studies have repeatedly demonstrated that the application of the vehicle for psychostimulants, i.e. saline, to control groups, generated different behavioral test results compared to absolute naïve controls (i.e. without any injection). Therefore, our present study has set three goals: (1) to evaluate the effect of three different psychostimulant drugs, (2) to evaluate the effect of three doses of delta 9-tetrahydrocannabinol (THC), and (3) to evaluate the effect of saline and ethanol injections vs sham injections and no injection on spontaneous behavior of adult male rats. The LABORAS test (Metris B.V., Netherlands) was used to examine spontaneous locomotor activity and exploratory behavior in an unknown environment over $1 \mathrm{~h}$. In Experiment 1, psychostimulant drugs were tested: single subcutaneous (s.c.) injections of amphetamine $(5 \mathrm{mg} / \mathrm{kg})$, cocaine $(5 \mathrm{mg} / \mathrm{kg})$, and 3,4-methylenedioxymethamphetamine (MDMA) (5 mg/kg) were applied prior to testing. Control animals received the same volume $(1 \mathrm{ml} / \mathrm{kg})$ of s.c. saline. In Experiment 2, the effect of three doses of THC $(1,2$, and $5 \mathrm{mg} / \mathrm{kg}$, s.c.) were examined. An s.c. injection of vehicle (ethanol) was used as a control. In Experiment 3, injections of saline and ethanol were compared to the group receiving a sham s.c. injection and to a group of absolute "naïve" controls. Our results demonstrated that (1) all psychostimulants increased locomotion time, distance traveled, and speed while decreasing immobility time of adult male rats relative to saline controls. The most prominent effect was associated with MDMA; (2) The effect of THC was dosedependent and was most apparent within the first $10 \mathrm{~min}$ of the LABORAS test. (3) With regard to the effect of injection: absolute controls (without injection) compared to animals injected with ethanol, saline, or sham-injected displayed reduced immobility time, traveled longer distances, and had increased speed. In conclusion, our data showed drug dependent behavioral changes in adult male rats after application of psychostimulants and cannabinoids. Our findings also suggest that not only drugs but the actual single injection per se also affects the behavior of laboratory animals in an unknown environment. This effect seems to be associated with the acute stress associated with the injection.

\section{Key words}

Amphetamine • MDMA • Cocaine • THC • Behavior • LABORAS test $\bullet$ Injection

\section{Corresponding author}

R. Šlamberová, Department of Physiology, Third Faculty of Medicine, Charles University, Ke Karlovu 4, 12000 Praha 2, Czech Republic. Fax: + 420224902750 . E-mail: romana.slamberova@lf3.cuni.cz

\section{Introduction}

Psychostimulant drugs have been shown to significantly affect a great variety of behaviors in humans (Sommers et al. 2006) and laboratory animals (Hayase et al. 2005, Hayase et al. 2006). In humans, psychostimulants evoke either positive emotions of joy and happiness or suppress negative states of anxiety or types of depression (Nesse and Berridge 1997). In extreme cases, chronic exposure to psychostimulant drugs may result in aggressive psychosis and paranoia (McGregor et al. 2008). Individuals suffering from substance use disorders often show severely impaired social interaction, preferring drugs of abuse over social interaction (Zernig et al. 2013). Long-lasting alterations 
in the emotional state, such as fear, anxiety, social receptivity, depressive symptoms as well as memory deficit, have been demonstrated in laboratory rats given psychostimulants (Hayase et al. 2005, McGregor et al. 2003, Navarro et al. 2004, Páleníček et al. 2005, Schutová et al. 2009, Thompson et al. 2008, Williams et al. 2003), which matches the long-term changes reported in human studies (Clemens et al. 2007). Animal studies examining the effects of acute application of psychostimulants have reported anxiolytic-like effects in various animal models, even though there is substantial evidence supporting anxiogenic-like effects as well (Navarro et al. 2004, Paine et al. 2002).

All of the most frequently abused psychostimulant drugs (amphetamines, cocaine, 3,4-methylenedioxymethamphetamine (MDMA)) are known to affect the noradrenergic, dopaminergic, and serotoninergic systems of the brain. The ratio of involvement of these neurotransmitter systems differs between the mentioned psychostimulant drugs. While amphetamines seem to mostly affect the noradrenergic, followed by the dopaminergic and then the serotoninergic system, cocaine and MDMA seem to mostly affect the serotoninergic system (Fleckenstein et al. 2000, Rothman et al. 2001, Shoblock et al. 2003). Therefore, the first goal of the present study was to compare the effect of the three psychostimulant drugs (amphetamine, cocaine, MDMA) on the behavior of adult male rats in an unknown environment.

Similarly, to psychostimulants, cannabinoids also have varied effects on behavior, which are dosedependent (Katsidoni et al. 2013). At this time, 66 phytocannabinoids have been identified, with the most common being: cannabigerol ( $\mathrm{CBG})$, cannabichromene (CBC), cannabidiol (CBD), $\Delta$ 9-tetrahydrocannabinol (THC), and $\triangle 8$-THC (Elsohly and Slade 2005). THC is the most psychoactive cannabinoid extracted from marihuana. Of the known cannabinoid receptors, only CB1 are normally found in the brain, spinal cord, and peripheral nervous system (Pertwee 1997). Activation of $\mathrm{CB} 1$ receptor produces marijuana-like effects on behavior and the circulation, while activation of $\mathrm{CB} 2$ does not. THC has an approximately equal affinity for $\mathrm{CB} 1$ and $\mathrm{CB} 2$, however, its effectiveness is less at $\mathrm{CB} 2$ than at CB1 receptors (Grotenhermen 2004). Even though THC primarily acts at cannabinoid receptors, it also indirectly increases dopamine release (Johnson and North 1992, Szabo et al. 2002) and stimulates serotonin-mediated neurotransmission after acute treatment (Johnson et al.
1981, Macúchová and Šlamberová 2017).

The effect of THC is characterized by a unique psychological mixture of depressant and stimulant effects, which can be divided into four groups: affective (euphoria, enhanced well-being, anxiety), sensory (increased perception of external stimuli), somatic (a feeling that the body floating), and cognitive (disturbed memory, difficulty concentrating). It is still under discussion whether heavy regular use may impair cognition, however, a disruption of sensory processing and impaired learning and memory have already been reported in humans after chronic THC administration (D'Souza et al. 2004). A cessation of long-term administration of THC has been shown to lead to withdrawal symptoms including insomnia, sweating, and inner unrest. Although these symptoms are mild, and the risk of physical and psychic dependency is low compared to other drugs of abuse (Grotenhermen 2004), it seems that the THC dose plays an important role in its effect. Our previous studies demonstrated diverse THC effects on cognition, social behavior, and active drug-seeking behavior, however, this diversity was due to the different doses administered (Macúchová et al. 2017, Macúchová et al. 2016, Šlamberová et al. 2016). Thus, the second goal of the present study is to examine the psychostimulant effect of three different doses of THC on behavior in an unknown environment.

In addition, our previous studies repeatedly demonstrated that behavior of saline-injected controls differed from absolute naïve controls (i.e. without injection) (Bernášková et al. 2017, Holubová et al. 2017, Šlamberová et al. 2002). Studies by other research teams have also found that saline injection can act as a stressor (Drago et al. 2001, Kiyatkin and Lenoir 2011, Raap et al. 2000). However, none of the studies examined if it was the effect of saline or of the injection per se. Therefore, the third goal of the present study was to test the effect of two different vehicles (saline and ethanol) (s.c.) injections plus sham injections (s.c.) compared to a naïve control group (i.e. without injection, sham or otherwise).

As in our previous studies (Macúchová and Šlamberová 2017, Schutová et al. 2013), the LABORAS apparatus (Metris B.V., Netherlands) was used to examine the effect of psychostimulant drugs and the effect of injections on the behavior of animals in an unknown environment. 


\section{Methods}

The procedures for animal experimentation applied in this study were reviewed and approved by the Institutional Animal Care and Use Committee and are in agreement with the Czech Government Requirements under the Policy of Human Care of Laboratory Animals (No. 246/1992) and with subsequent regulations of the Ministry of Agriculture of the Czech Republic (No. 311/1997).

\section{Animals}

80 adult male albino Wistar rats (PD 70-90) were delivered by Velaz (Prague, Czech Republic) from Charles River Laboratories International, Inc. Animals were housed four per cage and left undisturbed to adapt for one week in a temperature-controlled $\left(22-24{ }^{\circ} \mathrm{C}\right)$ colony room with free access to food and water on a reversed $12 \mathrm{~h}$ (light): $12 \mathrm{~h}$ (dark) cycle with lights off at 06:00.

\section{Drug treatment}

Three experiments were conducted as described below. The animals were randomly assigned to groups. All 3 experiments were run in parallel. Since experiments were carried out using only two LABORAS platforms, the animals from all 3 experiments were tested alternately to avoid tampering with the environment or with a group from the same cage.

\section{Experiment 1}

Psychostimulant drugs ( $\mathrm{n}=8$ per group), amphetamine $(5 \mathrm{mg} / \mathrm{ml} / \mathrm{kg})$, cocaine $(5 \mathrm{mg} / \mathrm{ml} / \mathrm{kg})$, or MDMA ( $5 \mathrm{mg} / \mathrm{ml} / \mathrm{kg}$ ), were administered subcutaneously (s.c.), under the skin behind the neck, immediately prior to testing. The group administered saline $(1 \mathrm{ml} / \mathrm{kg})$ was used as a control to compare the effects of psychostimulants.

\section{Experiment 2}

The most potent cannabinoid with psychostimulant effect, THC ( $\mathrm{n}=8$ per group), was dissolved in ethanol and administered s.c. in different doses $(1,2$, and $5 \mathrm{mg} / \mathrm{kg})$. Controls for THC were administered the same concentration and volume of ethanol $(7.2 \%$ ethanol at $1 \mathrm{ml} / \mathrm{kg})$.

\section{Experiment 3}

Different control groups ( $\mathrm{n}=8$ per group) were compared - (1) single s.c. injection with physiological saline (1 $\mathrm{ml} / \mathrm{kg})$, (2) single s.c. ethanol injection ( $7.2 \%$ ethanol at $1 \mathrm{ml} / \mathrm{kg})$, (3) single s.c. sham injection, and (4) naïve controls without injection.

\section{Behavioral testing}

Behavioral testing took place in the morning (from 8 am to $11 \mathrm{am}$ ) in a darkened room. Because the animals were housed on a reversed light/dark cycle, they were tested during their active period.

Animals received s.c. injections of the tested drug or vehicle in a volume of $1 \mathrm{ml} / \mathrm{kg}$ immediately prior to testing in the LABORAS apparatus, which was situated in a dark room. The LABORAS is a fully automated system for continuous behavior recognition and tracking of small rodents as described by Schutová et al. (2013). The behavior of the animals was recorded for $1 \mathrm{~h}$. The animals were not habituated to the apparatus beforehand, so their first exposure to the novel environment was on the day of the testing. As in our previous study (Schutová et al. 2013), the 1-hour period was divided to six 10-minute intervals (Intervals), so we could follow the changes in behavior during the habituation time in the LABORAS apparatus.

The following parameters were automatically evaluated by LABORAS: time spent in locomotion [s], time spent immobile [s], time spent rearing [s], time spent grooming [s], distance (trajectory length) [m], and average speed $[\mathrm{mm} / \mathrm{min}]$.

\section{Statistical analysis}

A One-way ANOVA (Injection) with Repeated Measure (Intervals) was used for each Experiment separately. The Bonferroni test was used for post-hoc comparisons. Differences were considered significant if $\mathrm{p}<0.05$.

\section{Results}

\section{Experiment 1}

As shown in Figure 1, MDMA increased locomotion $[\mathrm{F}(3,29)=22.43 ; \mathrm{p}<0.0001]$, increased distance traveled $[\mathrm{F}(3,28)=14.69 ; \mathrm{p}<0.0001]$ and increased average speed $[\mathrm{F}(3,28)=14.69 ; \mathrm{p}<0.0001]$ relative to saline controls and cocaine. In addition, amphetamine increased locomotion $[\mathrm{F}(15,140)=6.36$; $\mathrm{p}<0.0001]$, distance traveled $[\mathrm{F}(15,140)=3.02 ; \mathrm{p}<0.001]$ and average speed $[\mathrm{F}(15,140)=3.02 ; \mathrm{p}<0.001]$ relative to saline controls and cocaine but only within the first 
10-minute interval of the LABORAS test. Immobility was higher in the control group during the second half of the test period, i.e. starting at the $30^{\text {th }}$ minute, compared to all experimental groups $[F(3,28)=7.27 ; \mathrm{p}<0.001]$. There were no differences in the time spent rearing and grooming.
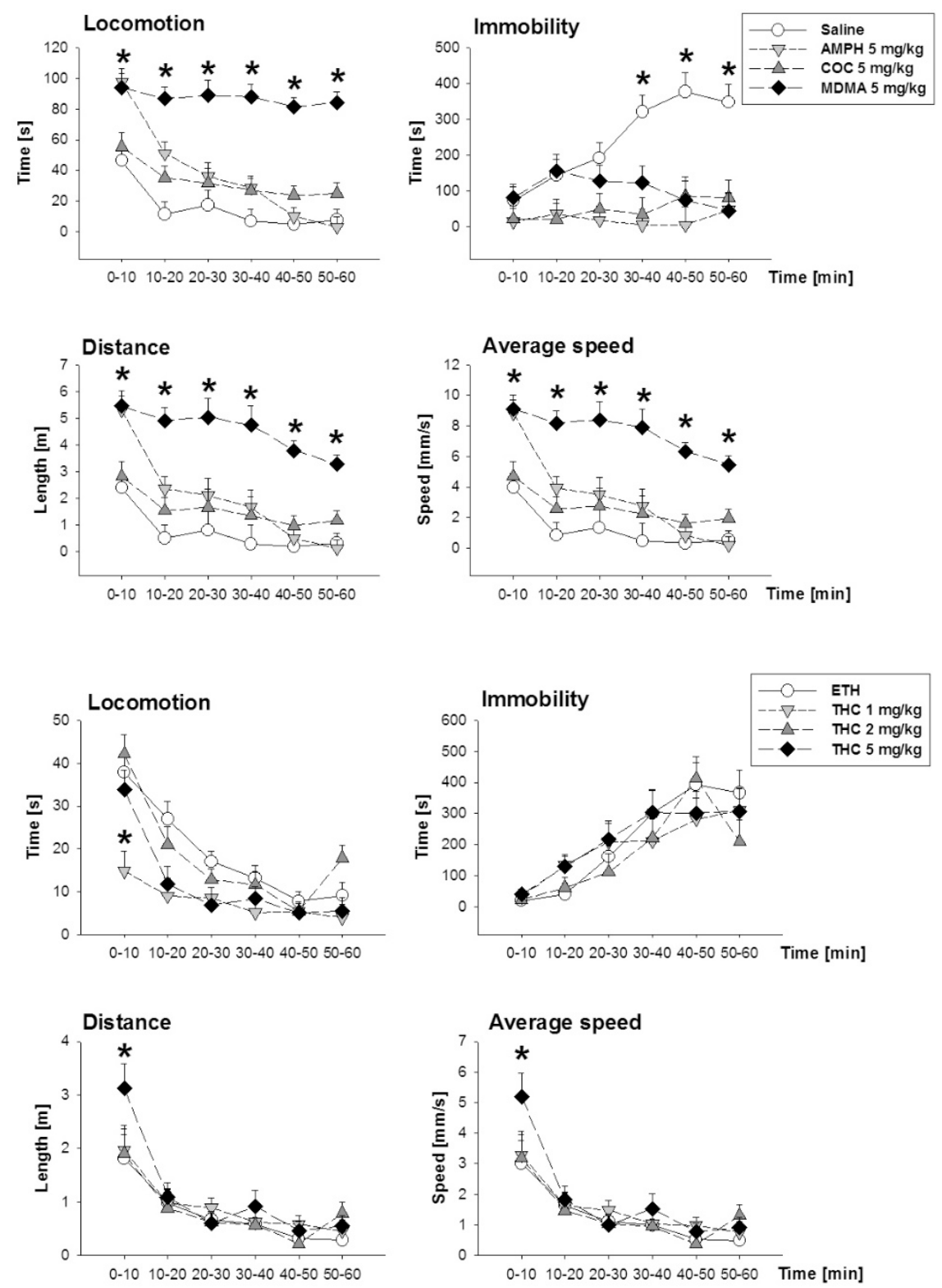

Fig. 1. The effect of psychostimulant drugs on behavior in the LABORAS test. $\mathrm{AMPH}=$ amphetamine; $\mathrm{COC}=\mathrm{CO}-$ caine; $\quad$ MDMA=3,4-methylene-dioxymethamphetamine. Values are mean $\pm \operatorname{SEM}(n=8) . * p<0.05$.

Fig. 2. The effect of three doses of THC on behavior in the LABORAS test. Values are mean \pm SEM $(n=8)$. $* p<0.05$.

\section{Experiment 2}

There were few differences in the effect of THC on the LABORAS test performance (Fig. 2). The lowest dose of $\mathrm{THC}(1 \mathrm{mg} / \mathrm{kg})$ shortened the time spent in locomotion $[\mathrm{F}(15,140)=3.39 ; \mathrm{p}<0.0001]$ during the first 10-minute interval relative to ethanol controls and higher doses of THC. On the other hand, the highest dose of THC $(5 \mathrm{mg} / \mathrm{kg})$ increased the distance traveled $[\mathrm{F}(15,140)=1.90 ; \quad \mathrm{p}<0.05]$ and average speed $[\mathrm{F}(15,140)=1.90 ; \mathrm{p}<0.05]$ during the first 10 -minute interval relative to ethanol controls and lower doses of
THC. There were no differences in the time spent rearing and grooming.

\section{Experiment 3}

As shown in Figure 3, naïve controls without any injection traveled longer distances $[\mathrm{F}(3,28)=18.25$; $\mathrm{p}<0.0001]$, had higher speed $[\mathrm{F}(3,28)=18.25 ; \mathrm{p}<0.0001]$ and spent less time immobile $[\mathrm{F}(3,28)=3.5910, \mathrm{p}<0.05]$ than the ethanol-, saline- and sham-injected groups. There were no differences in the time spent rearing and grooming. 


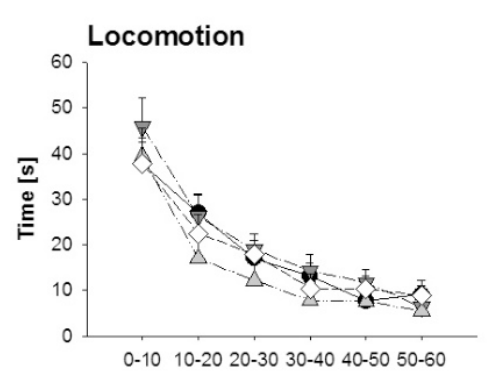

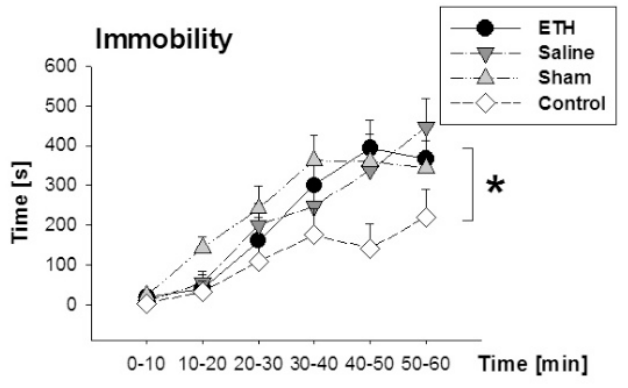

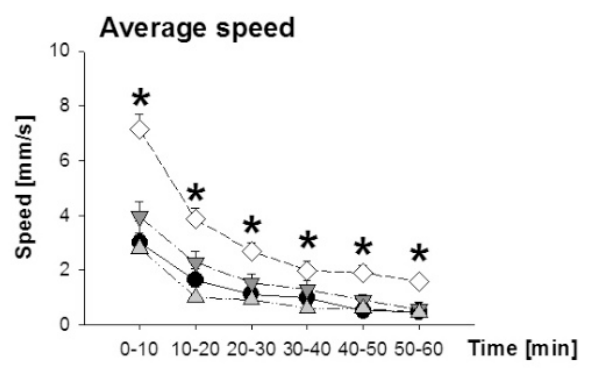

Fig. 3. The effect of different control injection on behavior in the LABORAS test. Values are mean $\pm \operatorname{SEM}(n=8)$. $* p<0.05$.

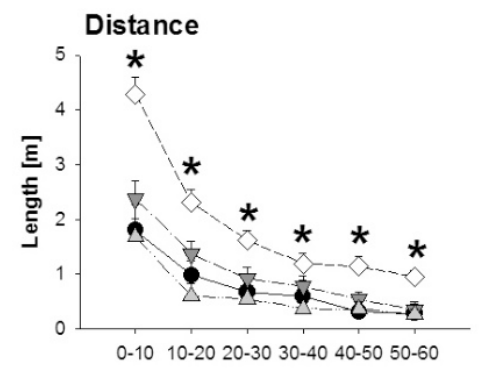

dependent effects of THC on spontaneous motor activity

\section{Discussion}

The present study was conducted in order to better understand the effect of psychotropic drugs and the effect of solvent and/or injections on spontaneous behavior of laboratory rats.

MDMA, when administered at a dose of $5 \mathrm{mg} / \mathrm{kg}$, increased locomotion, distance traveled, and average speed, as measured using the LABORAS test, more than any of the other tested psychostimulant drugs. The activity (locomotion, distance traveled, and speed) was also increased after amphetamine within the first 10-minute period (LABORAS test). Cocaine, on the other hand, did not increase locomotion at all. Amphetamines and their related drugs generally are known to increase locomotor activity, which seems to be associated with increased levels of dopamine (Bubeníková-Valešová et al. 2009, Zhang et al. 2001). The increase of horizontal activity induced by MDMA is dose-dependent (Gold et al. 1989) and therefore we suggest that an MDMA dose of $5 \mathrm{mg} / \mathrm{kg}$ was high enough to induce a greater response than the same dose of amphetamine, which could be considered as a low or medium dose, and thereby does not induce a substantial increase in locomotion (Gold et al. 1989, Zhang et al. 2001). Cocaine's lack of effect on locomotion is supported by our previous work (Šlamberová et al. 2015).

The effect of THC in the present study was dosedependent and affected only the first ten minutes of the test. While the highest dose $5 \mathrm{mg} / \mathrm{kg}$ increased speed, which also affected the distance traveled, the lowest dose $1 \mathrm{mg} / \mathrm{kg}$ decreased locomotion time. Biphasic dose- have been reported in several studies (Katsidoni et al. 2013, Wiley and Martin 2003). While low doses (e.g. $0.1 \mathrm{mg} / \mathrm{kg}$ ) of cannabinoids increase motor activity, higher doses $(1 \mathrm{mg} / \mathrm{kg})$ decrease it and produce catalepsy, although several pharmacological (i.e. dose and route of administration) and non-pharmacological (i.e. rat phenotype, habituation and reaction to novelty, influence of the light/dark cycle) factors can significantly influence these effects. It should be noted that the present study tested doses $\geq 1 \mathrm{mg} / \mathrm{kg}$. So, it is possible that the dosedependent effect of THC is not only biphasic but might be U-shaped. Moreover, McMahon and Koek (2007) reported that the hypoactivity induced by THC was maximum from 1 to $2 \mathrm{~h}$ after drug administration and was not detected after $4 \mathrm{~h}$. Because the present study tested animals for the effect of THC for only a 1-hour period, it is possible that a longer experiment might show other differences. Thus, future studies are planned to test the long-term effects of THC.

The most surprising effect of the drugs was the finding of that some drugs such as THC, at certain doses, and partially amphetamine and MDMA showed differences during the first ten minutes of the experiment. Moreover, the THC and amphetamine influenced locomotion only during the $0-10 \mathrm{~min}$ interval after s.c. injection, which then were normalized. This result is very hard to explain and therefore we can only speculate. Because the effect cannot be explained by pharmacokinetics (Hložek et al. 2017, Lucas et al. 2018, Rambousek et al. 2014), it is possible that these specific drugs might somehow induce local effects that might 
affect behavior of the animal resulting in increased locomotion. Such effects might be due to local analgesic effect or due to some local stressful stimulus. This is however only speculation and will require further studies to be verified or refuted.

Regarding the injection-effect: naïve controls (without injection) compared to animals injected with ethanol, physiological saline, or sham injections, showed reduced periods of immobility, traveled longer distances, and had increased speed. So, our uncertainty about the effect of the injection per se or the effect of the solvent, especially the physiological saline, seems to be clarified. The present study clearly supports our hypothesis regarding the effect of injections per se. Thus, it seems that the injection (regardless of the solution injected) induces changes in the behavior of rats, which may be associated with the stress reaction and activation of the hypothalamic-pituitary-adrenal axis (Gomez and GarciaGarcia 2017).

In conclusion, our results show that in adult male rats administration of either psychostimulants or cannabinoids produced unique behavioral changes that appear to be dose-dependent. Our findings also suggest that not only drugs but also the injection itself can affect the behavior of laboratory animals in an unknown environment. This effect is thought to be associated with an acute stress response. Future studies are planned to investigate other types of experimental manipulations (e.g. different types of injection - subcutaneous versus intraperitoneal, the effect of prior handling, environmental condition, etc.) and make comparisons to results mentioned in an article by Lapin (Lapin 1995).

\section{Conflict of Interest}

There is no conflict of interest.

\section{Acknowledgements}

This work was supported by research program PROGRES Q 35, projects GAUK 706216, and 260388/SVV/2018 from Charles University and partially by grant project 18-03806S from the Grant Agency of the Czech Republic. The work was further supported by the ERDF/ESF project "PharmaBrain" (No. CZ.02.1.01/ 0.0/0.0/16_025/0007444). The authors express their appreciation to Thomas Secrest, for critical reading and editing of the manuscript.

\section{References}

BERNÁŠKOVÁ K, TOMKOVÁ S, ŠLAMBEROVÁ R: Are changes in excitability in the hippocampus of adult male rats induced by prenatal methamphetamine exposure or stress? Epilepsy Res 137: 132-138 2017.

BUBENÍKOVÁ-VALEŠOVÁ V, KAČER P, SYSLOVÁ K, RAMBOUSEK L, JANOVSKÝ M, SCHUTOVÁ B, HRUBÁ L, ŠLAMBEROVÁ R: Prenatal methamphetamine exposure affects the mesolimbic dopaminergic system and behavior in adult offspring. Int J Dev Neurosci 27: 525-530, 2009.

CLEMENS KJ, CORNISH JL, HUNT GE, MCGREGOR IS: Repeated weekly exposure to MDMA, methamphetamine or their combination: Long-term behavioural and neurochemical effects in rats. Drug Alcohol Depend 86: 183-190, 2007.

D'SOUZA DC, PERRY E, MACDOUGALL L, AMMERMAN Y, COOPER T, WU YT, BRALEY G, GUEORGUIEVA R, KRYSTAL JH: The psychotomimetic effects of intravenous delta-9tetrahydrocannabinol in healthy individuals: implications for psychosis. Neuropsychopharmacology 29: 1558-1572, 2004.

DRAGO F, NICOLOSI A, MICALE V, Lo MENZO G: Placebo affects the performance of rats in models of depression: is it a good control for behavioral experiments? Eur Neuropsychopharmacol 11: 209-213, 2001.

ELSOHLY MA, SLADE D: Chemical constituents of marijuana: the complex mixture of natural cannabinoids. Life Sci 78: 539-548, 2005.

FLECKENSTEIN AE, GIBB JW, HANSON GR: Differential effects of stimulants on monoaminergic transporters: pharmacological consequences and implications for neurotoxicity. Eur J Pharmacol 406: 1-13, 2000.

GOLD LH, GEYER MA, KOOB GF: Neurochemical mechanisms involved in behavioral effects of amphetamines and related designer drugs. NIDA Res Monogr 94: 101-126, 1989.

GOMEZ F, GARCIA-GARCIA L: Anxiogenic-like effects of fluoxetine render adult male rats vulnerable to the effects of a novel stress. Pharmacol Biochem Behav 153: 32-44, 2017.

GROTENHERMEN F: Pharmacology of cannabinoids. Neuro Endocrinol Lett 25: 14-23, 2004. 
HAYASE T, YAMAMOTO Y, YAMAMOTO K: Persistent anxiogenic effects of a single or repeated doses of cocaine and methamphetamine: interactions with endogenous cannabinoid receptor ligands. Behav Pharmacol 16: 395-404, 2005.

HAYASE T, YAMAMOTO Y, YAMAMOTO K: Behavioral effects of ketamine and toxic interactions with psychostimulants. BMC Neurosci 7: 25, 2006.

HLOŽEK T, UTTL L, KADEŘÁBEK L, BALÍKOVÁ M, LHOTKOVÁ E, HORSLEY RR, NOVÁKOVÁ P, ŠÍCHOVÁ K, ŠTEFKOVÁ K, TYLŠ F, KUCHǍ̌ M, PÁLENÍČEK T: Pharmacokinetic and behavioural profile of THC, CBD, and THC+CBD combination after pulmonary, oral, and subcutaneous administration in rats and confirmation of conversion in vivo of CBD to THC. Eur Neuropsychopharmacol 27: 1223-1237, 2017.

HOLUBOVÁ A, ŠEVČÍKOVÁ M, MACÚCHOVÁ E, HREBÍČKOVÁ I, POMETLOVÁ M, ŠLAMBEROVÁ R: Effects of perinatal stress and drug abuse on maternal behavior and sensorimotor development of affected progeny. Physiol Res 66 (Suppl 4): S481-S491, 2017.

JOHNSON KM, DEWEY WL, BLOOM AS: Adrenalectomy reverses the effects of delta-9-THC on mouse brain 5-hydroxytryptamine turnover. Pharmacology 23: 223-229, 1981.

JOHNSON SW, NORTH RA: Opioids excite dopamine neurons by hyperpolarization of local interneurons. $J$ Neurosci 12: 483-488, 1992.

KATSIDONI V, KASTELLAKIS A, PANAGIS G: Biphasic effects of $\Delta 9$-tetrahydrocannabinol on brain stimulation reward and motor activity. Int J Neuropsychopharmacol 16: 2273-2284, 2013.

KIYATKIN EA, LENOIR M: Intravenous saline injection as an interoceptive signal in rats. Psychopharmacology (Berl) 217: 387-396, 2011.

LAPIN IP: Only controls: effect of handling, sham injection, and intraperitoneal injection of saline on behavior of mice in an elevated plus-maze. J Pharmacol Toxicol Methods 34: 73-77, 1995.

LUCAS CJ, GALETTIS P, SCHNEIDER J: The pharmacokinetics and the pharmacodynamics of cannabinoids. Br J Clin Pharmacol 84: 2477-2482, 2018.

MACÚCHOVÁ E, ŠEVČÍKOVÁ M, HREBÍČKOVÁ I, NOHEJLOVÁ K, ŠLAMBEROVÁ R: How various drugs affect anxiety-related behavior in male and female rats prenatally exposed to methamphetamine. Int $J$ Dev Neurosci 51: 1-11, 2016.

MACÚCHOVÁ E, NOHEJLOVÁ K, ŠEVČÍKOVÁ M, HREBÍČKOVÁ I, ŠLAMBEROVÁ R: Sex differences in strategies of spatial learning in prenatally-exposed rats treated with various drugs in adulthood. Behav Brain Res 327: 83-93, 2017.

MACÚCHOVÁ E, ŠLAMBEROVÁ R: Does prenatal methamphetamine exposure induce sensitization to drugs in adulthood? Physiol Res 66 (Suppl 4): S457-S467, 2017.

MCGREGOR IS, GURTMAN CG, MORLEY KC, CLEMENS KJ, BLOKLAND A, LI KM, CORNISH JL, HUNT GE: Increased anxiety and "depressive" symptoms months after MDMA ("ecstasy") in rats: drug-induced hyperthermia does not predict long-term outcomes. Psychopharmacology (Berl) 168: 465-474, 2003.

MCGREGOR IS, CALLAGHAN PD, HUNT GE: From ultrasocial to antisocial: a role for oxytocin in the acute reinforcing effects and long-term adverse consequences of drug use? Br J Pharmacol 154: 358-368, 2008.

MCMAHON LR, KOEK W: Differences in the relative potency of SR 141716A and AM 251 as antagonists of various in vivo effects of cannabinoid agonists in C57BL/6J mice. Eur J Pharmacol 569: 70-76, 2007.

NAVARRO JF, RIVERA A, MALDONADO E, CAVAS M, DE LA CALLE A: Anxiogenic-like activity of 3,4-methylenedioxy-methamphetamine ("Ecstasy") in the social interaction test is accompanied by an increase of c-fos expression in mice amygdala. Prog Neuropsychopharmacol Biol Psychiatry 28: 249-254, 2004.

NESSE RM, BERRIDGE KC: Psychoactive drug use in evolutionary perspective. Science 278: 63-66, 1997.

PAINE TA, JACKMAN SL, OLMSTEAD MC: Cocaine-induced anxiety: alleviation by diazepam, but not buspirone, dimenhydrinate or diphenhydramine. Behav Pharmacol 13: 511-523, 2002.

PÁLENÍČEK T, VOTAVA M, BUBENÍKOVÁ V, HORÁČEK J: Increased sensitivity to the acute effects of MDMA ("ecstasy") in female rats. Physiol Behav 86: 546-553, 2005.

PERTWEE RG: Pharmacology of cannabinoid CB1 and CB2 receptors. Pharmacol Ther 74: 129-180, 1997. 
RAAP DK, MORIN B, MEDICI CN, SMITH RF: Adolescent cocaine and injection stress effects on the estrous cycle. Physiol Behav 70: 417-424, 2000.

RAMBOUSEK L, KAČER P, SYSLOVÁ K, BUMBA J, BUBENÍKOVÁ-VALEŠOVÁ V, ŠLAMBEROVÁ R: Sex differences in methamphetamine pharmacokinetics in adult rats and its transfer to pups through the placental membrane and breast milk. Drug Alcohol Depend 139: 138-144, 2014.

ROTHMAN RB, BAUMANN MH, DERSCH CM, ROMERO DV, RICE KC, CARROLL FI, PARTILLA JS: Amphetamine-type central nervous system stimulants release norepinephrine more potently than they release dopamine and serotonin. Synapse 39: 32-41, 2001.

SHOBLOCK JR, SULLIVAN EB, MAISONNEUVE IM, GLICK SD: Neurochemical and behavioral differences between d-methamphetamine and d-amphetamine in rats. Psychopharmacology (Berl) 165: 359-369, 2003.

SCHUTOVÁ B, HRUBÁ L, POMETLOVÁ M, DEYKUN K, ŠLAMBEROVÁ R: Cognitive functions and drug sensitivity in adult male rats prenatally exposed to methamphetamine. Physiol Res 58: 741-750, 2009.

SCHUTOVÁ B, HRUBÁ L, ROKYTA R, ŠLAMBEROVÁ R: Gender differences in behavioral changes elicited by prenatal methamphetamine exposure and application of the same drug in adulthood. Dev Psychobiol 55: 232-242, 2013.

SOMMERS I, BASKIN D, BASKIN-SOMMERS A: Methamphetamine use among young adults: health and social consequences. Addict Behav 31: 1469-1476, 2006.

SZABO B, SIEMES S, WALLMICHRATH I: Inhibition of GABAergic neurotransmission in the ventral tegmental area by cannabinoids. Eur J Neurosci 15: 2057-2061, 2002.

ŠLAMBEROVÁ R, SCHINDLER CJ, VATHY I: Impact of maternal morphine and saline injections on behavioral responses to cold water stressor in adult male and female progeny. Physiol Behav 75: 723-732, 2002.

ŠLAMBEROVÁ R, MIKULECKÁ A, MACÚCHOVÁ E, HREBÍČKOVÁ I, ŠEVČÍKOVÁ M, NOHEJLOVÁ K, POMETLOVÁ M: Effects of psychostimulants on social interaction in adult male rats. Behav Pharmacol 26: 776-785, 2015.

ŠLAMBEROVÁ R, MIKULECKÁ A, MACÚCHOVÁ E, HREBÍČKOVÁ I, ŠEVČÍKOVÁ M, NOHEJLOVÁ K, POMETLOVÁ M: Morphine decreases social interaction of adult male rats, while THC does not affect it. Physiol Res 65 (Suppl 5): S547-S555, 2016.

THOMPSON VB, HEIMAN J, CHAMBERS JB, BENOIT SC, BUESING WR, NORMAN MK, NORMAN AB, LIPTON JW: Long-term behavioral consequences of prenatal MDMA exposure. Physiol Behav 96: 593-601, 2008.

WILEY JL, MARTIN BR: Cannabinoid pharmacological properties common to other centrally acting drugs. Eur J Pharmacol 471: 185-193, 2003.

WILLIAMS MT, MORAN MS, VORHEES CV: Refining the critical period for methamphetamine-induced spatial deficits in the Morris water maze. Psychopharmacology (Berl) 168: 329-338, 2003.

ZERNIG G, KUMMER KK, PRAST JM: Dyadic social interaction as an alternative reward to cocaine. Front Psychiatry 4: 100, 2013.

ZHANG Y, LOONAM TM, NOAILLES PA, ANGULO JA: Comparison of cocaine- and methamphetamine-evoked dopamine and glutamate overflow in somatodendritic and terminal field regions of the rat brain during acute, chronic, and early withdrawal conditions. Ann N Y Acad Sci 937: 93-120, 2001. 